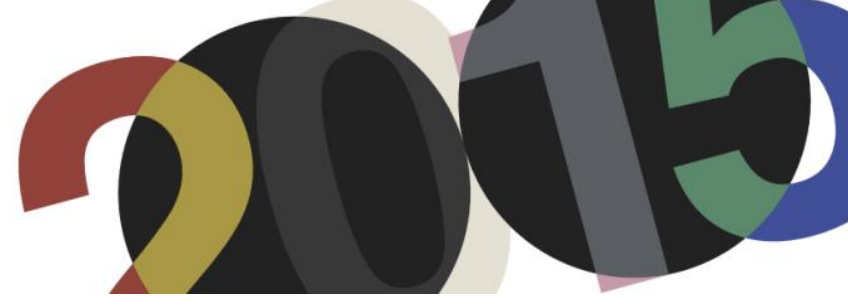

DOI: http://dx.doi.org/10.4995/LC2015.2015.677

\title{
La Réaction Poétique of a Prepared Mind
}

\author{
M. Mindrup \\ University of Sydney, Australia
}

\begin{abstract}
This paper explores Le Corbusier's practice of collecting and studying everyday objects as inspiration for new architectural ideas. An avid collector of 'objets trouves' that Le Corbusier referred to specifically as 'objets à réaction poètique,' he promoted their use claiming they gave direction to an imagination that alone might not be able to detect. Perhaps the most famous object in Le Corbusier's collection was a crab shell that he used as inspiration for the design of the roof for his Notre-Dame du Haut chapel in Ronchamp, France. Although Le Corbusier's use of this shell is well documented in studies on his oeuvre, little attention has been given to the role he intended found objects to play in his design process. In themselves these objects, which have their own identities as shells, pinecones or pieces of bone, they do not immediately lend themselves to any architectural solution. Rather, they are evidence of Le Corbusier's unique approach to design that relies on a what Louis Pasteur referred to as a 'prepared mind,' availed of all relevant data and information pertaining to a task, that can search for solutions in random object or events by spontaneously shift back and forth between analytic and associative modes of thought.
\end{abstract}

Keywords: Architectural model, Ronchamp, Design method, Imagination, Play, Objet trouve.

\section{Introduction}

Throughout his career, the Swiss architect, Le Corbusier was an avid collector of everyday objects and recorder of architectural ideas, which he used as inspiration for architectural designs. Perhaps the most famous object in Le Corbusier's collection was a crab shell, which became the structural model for the roof of his Notre Dame du Haut chapel in Ronchamp, France (completed 1955). An experienced designer like Corbusier knows that the design and construction of architecture rarely goes according to plan. Unexpected problems, mistranslations and accidental discoveries can permeate the design process producing surprising results. Clearly, retaining these objects and sketches had some ultimate purpose for Le Corbusier. Much overlooked by scholarship on Le Corbusier's oeuvre, is the role his collections played in the design process.

According to his own testimony, Le Corbusier was roaming a Long Island beach in the 1940s, when he came across the empty crab shell whose strength as two curvilinear surfaces joined at the edges activated his imagination. ${ }^{1}$ Le Corbusier kept this shell in a small case of natural objects including a pinecone, a bone, worn stones, and a nautilus shell as "objets à réaction poètique" (objects of poetic reaction). In his tract Entretien avec les étudiants des écoles d'architecture (Le Corbusier Talks with Students from the Schools of Architecture) of 1942 he explained how these objects "form the vast panoply of spokesmen who speak the language of nature. They are caressed by your hands, your eyes gaze upon them, they are evocative companions ..." ${ }^{2}$ For Le Corbusier, an object having poetic potential, must prompt speculation, engaging the mind to contemplate the

\footnotetext{
${ }^{1}$ Le Corbusier, The Chapel at Ronchamp (Frederick A. Praeger, 1957), p. 89-90.

${ }^{2}$ Le Corbusier, Le Corbusier Talks with Students from the Schools of Architecture, trans. Pierre Chase (New York: Princeton Architectural Press, 1999), p. 70-71. First published as Entretien avec les étudiants des écoles d'architecture (Paris: Denoël, 1943).
} 
efficacy of its forms that may lay outside the architect's accustomed architectural vocabulary. In themselves, Le Corbusier's "objets à réaction poètique" have no recognizable architectural purpose until they became a necessary factor for the architect, giving direction to the their imagination.

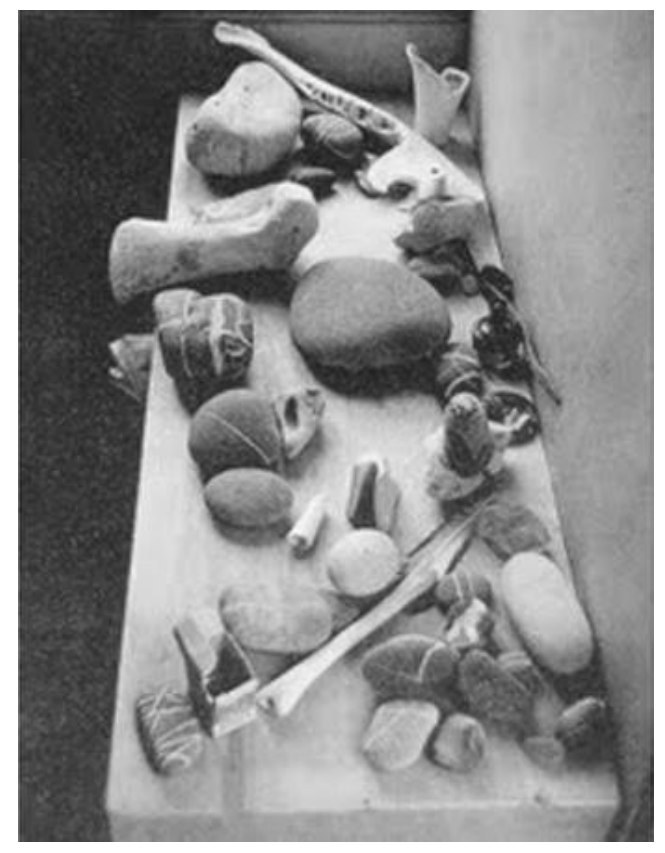

1. Le Corbusier, “Objets à réaction poètique” (objects of poetic reaction), 1925-65.

In the design of architecture, sudden moments of creativity like that Le Corbusier experienced with the crab shell are made possible by what the French chemist and microbiologist, Louis Pasteur described as a "preparedmind," a mind actively engaged in a problem prepared to recognize an everyday object or event as inspiration for architecture. For cognitive scientists, this form of engagement is dependent upon the human capacity to spontaneously shift back and forth between analytic and associative modes of thought. For the Spanish artist Pablo Picasso, Le Corbusier's collections are evidence of a sagacious individual who has learned to harness aberrations in the creative process claiming, "Inspiration exists, but it has to find you working." As evidenced by Le Corbusier's collection of poetic objects, this paper explores the mutability between the everyday and the extraordinary through an examination of the cognitive relationship between the model and its translation to architecture.

\section{Precedents}

Already at an early stage of his career as an architect, Le Corbusier developed an approach to design that was dependent upon a use of precedents for inspiring new architectural ideas. The emulation of classical precedents in antiquity was a dominant pedagogical method amongst European professional schools at the turn of the twentieth century. ${ }^{3}$ At the École des Art Décoratifs in La Chaux-de-Fonds, a small town in the eastern region of Switzerland know as the Jura, Le Corbusier studied the decorative arts under Charles L'Eplattenier, the man he

\footnotetext{
${ }^{3}$ Pierre Saddy, "le passé à réaction poétique," in Pierre Saddy, ed., Le Corbusier: le passé à réaction poétique (Paris: Caisse Nationale des Monuments Historiques et des Sites, 1988), p. 15-27.
} 
would later call his only teacher. ${ }^{4}$ As director of the Ecole, L'Eplattenier was less interested in teaching his students "styles" than an underlying attitude toward nature and art. Rather, L'Eplattenier's goal was to lay the groundwork amongst his students for the development of a regional Jura art inspired partly by local plant forms. It was through L'Eplattenier that Le Corbusier was introduced to Henry Provensal's 1904 published book on art and architectural theory, L'art de Demain (The Art of Today). Along with the guidance of L'Eplattenier; Le Corbusier's approach to design owes a debt to Provensal's writings.

In L'art de Demain (The Art of Today), Provensal proposes the idealistic assumption that there exists perfect formal principles or ideas, which can ultimately be discovered and embodied by the artist. The artist's role for Provensal is to connect man with the eternal principles of the "absolute." Throughout his life, Le Corbusier searched for universal formal principles that as Provensal claimed were found in "nature's crystallized forms" and could bring perfect order into architectural form. ${ }^{6}$ Already during his famous voyage to the Orient, Le Corbusier did not record in his travel log the precise construction and structure of buildings but their origins as squares, cubes, spheres or cylinders with the Parthenon in Athens being a 'cube. ${ }^{7}$ Le Corbusier's preference for geometric forms was fostered by his friendship and ensuing collaboration with the French painter and designer Amédée Ozenfant. An advocate of Cubism, Ozenfant introduced Le Corbusier to modern art, painting and his own art movement, 'purism.' In 1918 (a few months after they met) Ozenfant and Jeanneret published Apres le Cubism. ${ }^{8}$ Their aim was to purify cubism by stripping it of its decorative features and basing their austere geometrical shapes on machine forms. In the third chapter the authors argue that this new art must generalize, must discover the natural laws that both art and science depend. ${ }^{9}$ When properly understood, nature is to be seen as a perfect 'machine' working according to geometric and mathematical principles. Just over a year later Ozenfant and Le Corbusier began publishing an avant-garde magazine on art and architecture called L'esprit Nouveau. ${ }^{10}$ Despite the double signature, the articles on architecture were written primarily by Le Corbusier, which he incorporated into his 1923 published book Vers une Architecture (Towards an Architecture). ${ }^{11}$ In the chapter "The Lesson of Rome" we find Le Corbusier's use of the Roman monuments to argue for an architecture composed of pure geometric forms ${ }^{12}$. Late in his career, Le Corbusier abandoned his pursuit of geometric rationalism for the design of his the chapel, Notre Dame du Haut in Ronchamp, France.

\footnotetext{
${ }^{4}$ H A. Brooks, Le Corbusier's Formative Years: Charles-edouard Jeanneret at La Chaux-De-Fonds (Chicago: University of Chicago Press, 1997), pp. 23-91.

${ }^{5}$ Henry Provensal, L'Art de demain (Paris: Perrin, 1904), p. 143 after Brooks, p. 70.

${ }^{6}$ Provensal, p. 162.

${ }^{7}$ Le Corbusier, Journey to the East, trans. Ivan Žaknić (Cambridge, Mass: MIT Press, 2007), p. 104 and 212.

${ }^{8}$ Amédée Ozenfant and Charles-Edouard Jeanneret, “After Cubism," translated by John Goodman in Carol S. Eliel, L'Esprit Nouveau: Purism in Paris, 1918-1925 (New York: Harry N. Abrams, Inc., 2001), pp.150-158.

${ }^{9}$ Ibid., pp.150-158

${ }^{10}$ Eliel, L'Esprit Nouveau: Purism in Paris, pp. 23-24.

${ }^{11}$ Le Corbusier-Saugnier, Vers une Architecture (Paris: Éditions G. Cres et Cie., 1923).

${ }^{12}$ Le Corbusier, Toward an Architecture, translated by John Goodman (Los Angeles: Getty Research Institute, 2007), p. 200.
} 


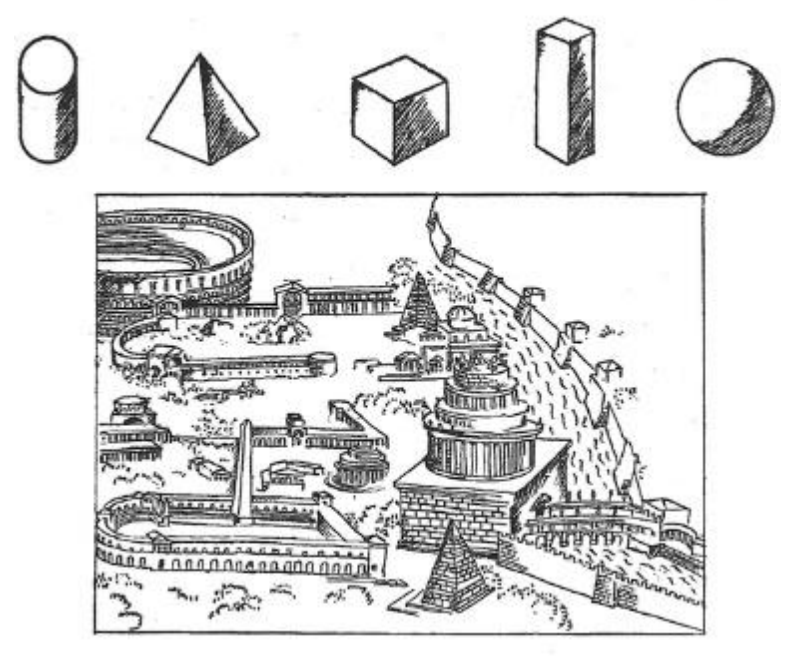

2. Le Corbusier, Sketch of Roman ruins and primary solids in Vers une Architecture, 1923.

Despite its organically determined form, Le Corbusier's chapel at Ronchamp should not be seen as a turn away from his search for universal principles to generate new designs. In Le Corbusier's chapel, three white towers rise up from thick gently curving walls circumscribing and illuminating a space for congregation. Floating $10 \mathrm{~cm}$ above the entirety rests a massive double-shelled curvilinear roof giving the chapel the impression of a white ship or a nun's cowl. In a review of the chapel entitled "Le Corbusier's Chapel and the Crisis of Rationalism," James Stirling noted a change in Le Corbusier's from "forms which have developed from the rationale and the initial ideology of the modern movement are being mannerized and changed into a conscious imperfectionism." 13 Yet, for Stirling, Le Corbusier has not completely abandoned functional rationality observing how "[a]s a religious building, it functions extremely well." ${ }^{, 14}$ Rather, in what must be a reference to Le Corbusier's use of precedents, Stirling noted how "travels round the world have stockpiled [Le Corbusier's] vocabulary with plastic elements and objets trouves of considerable picturesqueness." ${ }^{.15}$ Here Stirling seems to be referring to Le Corbusier's use of "objets à réaction poètique." Already in 1943 Le Corbusier lauded their value in the design process. One that he in 1960 claimed could offer him an "eloquent lesson ... bringing a wealth to the mind that it alone cannot detect." ${ }^{, 16}$ But these shells, bones, pinecones, etcetera have their own identities as bits and pieces of natural flotsam and jetsam that alone do not suggest architecture or models for it. Their use requires a mind that is prepared to see them as architecture.

\footnotetext{
${ }^{13}$ James Stirling, "Ronchamp: Le Corbusier's Chapel and the Crisis of Rationalism, ” Architectural Review 119 (1956): 160 61.

${ }^{14}$ Ibid.

${ }^{15}$ Ibid.

${ }^{16}$ Le Corbusier, "Les objets à réaction poétique," in Le Corbusier, L'Atelier de la Recherche patiente (Paris: Vincent et Fréal, 1960), p. 209.
} 


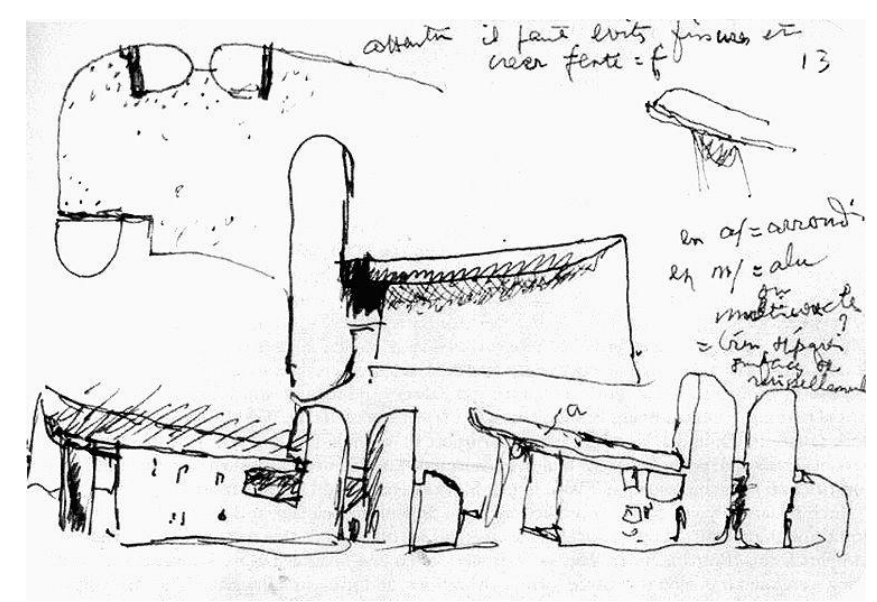

3. Le Corbusier, Studies for Notre Dame du Haut, Ronchamp, c. 1951.

\section{A Prepared Mind for Musement}

To claim moments of inspiration a designer must possesses a 'prepared eye' which is able to take advantage of stimuli they encounter, randomly or intentionally. With every new project, the designer is faced with a new set of requirements and conditions. Although they may avail themselves of all relevant data and information pertaining to the task, this alone will not directly translate into a design solution. Conversely, random trial and error may aid an architect's purposeful search but it cannot act as a substitute for it. As Louis Pasteur remarked in a speech to the Faculty of Sciences at Lille, "fortune favors the prepared mind."17 To recognize an everyday object or event as inspiration for architecture, a designer's mind must be actively engaged in a problem. The French architect Le Corbusier kept a collection of found objects in his studio to encourage precisely these random moments of invention that in one case inspired the roof design for his Chapel of Notre-Dame du Haut in Ronchamp, France.

What Le Corbusier's use of the crab shell demonstrates is that accidental moments of creativity are dependent on the designer having experiences upon which they can make hypothetical associations-projections. One can image how standing over his objets à réaction poètique, Le Corbusier uses his shells, bones and other natural objet trouves much like a shaman in an act of divination. For Carl Jung this is likened to "synchronicity" in which the diviner is in a subjective state and finds a meaningful connection between two acausally connected events. $^{18}$

The American philosopher, Charles Sanders Peirce describes the formation of a hypothesis as "an act of insight," which makes the most sense given observed phenomenon or data and based on prior experience. Compared to the creative activity of an architect, Pierce's concept of abduction essentially describes a situation in which the subject is confronted with an observed fact needing explanation. An abductive affordance comes to a subject in a flash which, like Le Corbusier's use of object trouves, "it is the idea of putting together what we had never

\footnotetext{
${ }^{17}$ Louis Pasteur, "Dans les champs de l'observation le hazard ne favorise que les esprits reéparés." Lecture presented at the University of Lille, Douai, France, on December 7, 1854. H. Petersen, ed, A Treasury of the World's Great Speeches (New York: Simon Schuster, 1954), p. 473.

${ }^{18}$ C G. Jung, Synchronicity: An Acausal Connecting Principle, trans. R F. C. Hull (Princeton, N.J: Princeton University Press, 1973),
} 
before dreamed of putting together which flashes the new suggestion before our contemplation." ${ }^{\prime 19}$ To enable our imaginations to shift back and forth between analytic and associative modes of thought, Piece recommended the practice of Musement, an occupation of the mind that searches for "some connection" between two of the three Universes of Experience (Ideas, Brute Actuality, and Signs) "with speculation concerning its cause." 20 Nevertheless, in themselves, Le Corbusier's "objets à réaction poètique," have no recognizable architectural purpose until they became a necessary factor for the architect, giving direction to the their imagination. It is this ability of the imagination to shift between two causes for the same object underlies Le Corbusier's use of precedents.

\section{A Play with Causes}

In everyday practice, architects encounter a variety of sensorial stimuli both familiar and unfamiliar. Yet not every experience may inspire an architectural idea. In a discussion about how humans come to identify the things we experience as men, gold or trees, the seventeenth century English philosopher, John Locke reasoned that simple ideas, like those of a basket, acanthus plant and clay roof tile are invariably produced in our minds by their influence on our sense organs. According to Locke, we go through the world interrogating sensory experience, noticing which primary qualities regularly seem to cluster together-these are a things' size, shape, motion, number, or solidity as a single idea under a single name. ${ }^{21}$ Yet, in the process of acquiring understanding, the imagination is vulnerable to accidental encounters with things and, in order to know them, it must abstract-out the primary from the secondary qualities of a thing - those qualities including color, sound, taste, and odor, which resemble the causes for a thing. ${ }^{22}$

For Aristotle, these accidental discoveries are important events in the work of a designer. In Aristotle's epistemology he places a crucial condition on the certainty of knowledge: we think we have knowledge of a thing only when we have grasped its why, that is to say, its cause. ${ }^{23}$ This account is valid for our study in the sense that it applies to everything that requires an explanation, including artistic production and human action. Here Aristotle recognizes four types of cause that can be given to answer a why-question: the material, formal, efficient, and final cause. However, Aristotle's analysis of causality reaches a critical moment when he asks how those causes that result from chance (tuchē), as the happening by accident as opposed to by design, fit into the division of the four previously mentioned causes ${ }^{24}$ For Aristotle, those 'accidents' effected by an agent "capable of choosing" are different from what he refers to as automaton - natural accidents like being hit by a randomly falling rock. ${ }^{25}$ In the realm of design, affordances that result from chance (tuchē) are efficient causes, sources "that set processes in motion"- that are not determined by a final cause but whose outcomes are final causes determined by their agent, the designer. ${ }^{26}$

\footnotetext{
${ }^{19}$ Charles Sanders Peirce, "Pragmatism as the Logic of Abduction (Lecture VII)" in The Essential Peirce: Selected Philosophical Writings, Vol. 2 (Bloomington, IN: Indiana University Press, 1998), p. 227.

${ }^{20}$ Charles Sanders Peirce, “A Neglected Argument for the Reality of God,” in Ibid., p. 436.

${ }^{21}$ John Locke, Essay Concerning Human Understanding, (Book II, Section xii, 1) abridged and edited with an introduction by A.D. Woozley (London: Collins, 1964), p. 132.

${ }^{22}$ Ibid., (Book II, Sections ix-xi) pp. 119-134.

${ }^{23}$ Aristotle, The Physics, with an English translation by Philip H. Wicksteed and Francis M. Cornford, Vol. 1 (London: W. Heinemann, 1970), (194 b 17-20). Book 2, chapter 3, p. 129.

${ }^{24}$ Ibid., Book II, chapters 4-6, pp. 138-163.

${ }^{25}$ Ibid. (197b29)., Book II, chapters 6, p. 161.

${ }^{26}$ Ibid. (198a5), Book 2, Chapter 6, p. 163.
} 
This vulnerability is the hallmark of a playful imagination that can shift between different final causes for the same thing and essential to the use of found objects in a playful activity of make-believe. For two children, a game of make-believe begins when an agreement is made that, for example, a pile of snow is a fort. Kendall Walton, a philosopher on the points of coincidence between toys and art, has argued how this fort is a found object that children play with as a "prop" that "prompts" them to imagine what they might not otherwise be creative enough to invent on their own. By interpreting the pile of snow as a prop, they do not merely imagine a fort with turrets, a tower and a moat. Rather, they imagine that the actual heap of snow is itself a fort. ${ }^{27}$ For the German philosopher of hermeneutics, Hans-Georg Gadamer this act of play is particularly strong in the creative arts whereby the artist's (and here we also include the architect) engagement with a thing 'as if' it was a something else permits them to go beyond the limitations and conditions of their own imaginations. ${ }^{28}$ Without entirely dismissing what one already knows about a thing, Le Corbusier, like children with a pile of snow, held the identity of the crab shell in temporary suspense to imagine its material and formal characteristics as something else, the model the chapel roof. Immanuel Kant calls this mental state 'free play' in which our faculties of understanding and imagination cooperate with one another. ${ }^{29}$ That is to say that in the act of makebelieve a child creates a gap between the thing and idea enabling the object to be disengaged from what Paul Ricoeur described as the world behind it, its historical causes. ${ }^{30}$ For Umberto Eco this "disengagement" is particularly strong in the modern world, which generates in all of us "the feeling of senselessness, disorder, or 'discontinuity'," 31 In this conceptual moat, the imagination is free to posit other possibilities (causes) for everyday objects, including models of architecture, which are open to constant revision.

\section{Conclusion}

Le Corbusier once said that when he obtains a commission, he doesn't immediately start working on the project but lets it sit in his imagination for a few months. It is the mark of an experienced designer to avail themselves of all the issues related to a design project before they start working on it. One may say that the mind of the architect is in this way prepared for the occupation of Musement, a purposeless activity by which the imagination is disengaged, and open to speculate on final causes. The range of experiences an architect may draw upon certainly could also include those of everyday objects like Le Corbuiser's objets de reaction poetique. Yet, the moment of genius, the discovery of a fortuitous idea for putting together what we had never before considered, cannot be predetermined. Behind any strange tale of architectural evolution is a working architect, whose mind is prepared for a moment of inspiration.

\section{Bibliography}

Aristotle: The Physics, with an English translation by Philip H. Wicksteed and Francis M. Cornford, Vol. 1. London: W. Heinemann, 1970).

\footnotetext{
${ }^{27}$ Kendall Walton, Mimesis as make-believe: on the foundations of the representational arts (Cambridge, Mass.: Harvard University Press, 1990), p. 25.

${ }^{28}$ Hans-Georg Gadamer, "The play of art," in The Relevance of the Beautiful and other Essays, trans. Nicholas Walker and ed. Robert Bernasconi (Cambridge: Cambridge University Press, 1986), pp. 124-29.

${ }^{29}$ Immanuel Kant, Critique of Judgment, trans. James Creed Meredith and ed. Nicholas Walker (New York: Oxford University Press, 2009), p. 49.

${ }^{30}$ Paul Ricoeur, "The Hermeneutical Function of Distanciation," trans. David Pellauer, Philosophy Today 17, no. 2 (1973): 139-41.

${ }^{31}$ Umberto Eco, The Open Work, trans. Anna Cancogni (Cambridge, MA: Harvard University Press, 1989), p. xiv.
} 
Brooks, H A. Le Corbusier's Formative Years: Charles-edouard Jeanneret at La Chaux-De-Fonds. Chicago: University of Chicago Press, 1997.

Le Corbusier: The Chapel at Ronchamp. Frederick A. Praeger, 1957.

Le Corbusier: Le Corbusier Talks with Students from the Schools of Architecture. Translated by Pierre Chase. New York: Princeton Architectural Press, 1999. pp. 70-71. First published as Entretien avec les étudiants des écoles d'architecture. Paris: Denoël, 1943.

Le Corbusier: Journey to the East. Translated by Ivan Žaknić. Cambridge, Mass: MIT Press, 2007.

Le Corbusier: L'Atelier de la Recherche patiente. Paris: Vincent et Fréal, 1960.

Le Corbusier: Toward an Architecture. Translated by John Goodman. Los Angeles: Getty Research Institute, 2007.

Le Corbusier-Saugnier: Vers une Architecture. Paris: Éditions G. Cres et Cie., 1923.

Eco, Umberto: The Open Work. Translated by Anna Cancogni. Cambridge, MA: Harvard University Press, 1989.

Hans-Georg Gadamer, "The play of art," in The Relevance of the Beautiful and other Essays. Translated by Nicholas Walker. Edited by Robert Bernasconi. Cambridge: Cambridge University Press, 1986.

Jung, C G: Synchronicity: An Acausal Connecting Principle. Translated by R F. C. Hull. Princeton, N.J: Princeton University Press, 1973.

Kant, Immanuel: Critique of Judgment. Translated by James Creed Meredith and ed. Nicholas Walker. New York: Oxford University Press, 2009.

Locke, John: Essay Concerning Human Understanding. Abridged and edited with an introduction by A.D. Woozley. London: Collins, 1964.

Ozenfant, Amédée; Jeanneret, Charles-Edouard: "After Cubism.” Translated by John Goodman in Carol S. Eliel, L'Esprit Nouveau: Purism in Paris, 1918-1925. New York: Harry N. Abrams, Inc., 2001. pp. 150-158.

Provensal, Henry: L'Art de demain. Paris: Perrin, 1904.

Pasteur, Louis: "Dans les champs de l'observation le hazard ne favorise que les esprits reéparés." Lecture presented at the University of Lille, Douai, France, on December 7, 1854. H. Petersen, ed, A Treasury of the World's Great Speeches. New York: Simon Schuster, 1954. p. 473.

Peirce, Charles Sanders: "Pragmatism as the Logic of Abduction (Lecture VII)" in The Essential Peirce: Selected Philosophical Writings. Vol. 2. Bloomington, IN: Indiana University Press, 1998. p. 226-241.

Peirce, Charles Sanders: “A Neglected Argument for the Reality of God," in The Essential Peirce. p. 434-450.

Ricoeur, Paul: “The Hermeneutical Function of Distanciation.” Translated by David Pellauer, Philosophy Today 17, No 2. 1973. pp. 139-41.

Saddy, Pierre, ed. Le Corbusier: le passé à réaction poétique. Paris: Caisse Nationale des Monuments Historiques et des Sites, 1988.

Stirling, James: "Ronchamp: Le Corbusier's Chapel and the Crisis of Rationalism." Architectural Review, $\mathrm{N}^{\circ}$ 119. 1956. pp. 160-61.

Walton, Kendall: Mimesis as make-believe: on the foundations of the representational arts. Cambridge, Mass.: Harvard University Press, 1990. 